\title{
QUANDO A VIDA PEDE ESPERANÇA
}

\section{WHEN LIFE ASKS FOR HOPE}

Beatriz Maria de Figueiredo Ribeiro ${ }^{1}$

Durante o verão amazônico do ano de 2009, em pesquisa de campo numa área de assentamento da reforma agrária, na cidade de Eldorado dos Carajás - PA, comecei a ouvir de forma recorrente que fulano e beltrano tinham ido para o sem-terra. Havia sempre alguém indo ou voltando de lá. Por sem-terra, as pessoas do assentamento denominavam o acampamento do MST mais próximo; neste caso, tratava-se do Acampamento Dalcídio Jurandir, nome dado à ocupação realizada na Fazenda Maria Bonita, amplamente citada nos noticiários da mídia em 2008 por ter ocorrido, próximo ao local, conflitos violentos desencadeados por parte da escolta armada do Grupo Santa Bárbara - pretenso dono da área -, que rondava o acampamento dia e noite.

Cheguei ao acampamento às $11 \mathrm{~h} 30 \mathrm{~min}$ da manhã. Sol quente. A van parou em frente ao local onde era a antiga entrada da sede da fazenda. A parada era bem movimentada de pessoas e mercadorias, pois o comércio se fazia do lado de fora do acampamento. Da van, junto comigo, desceram mais duas pessoas para os sem-terra. De cara, vi o aceno de uma nova territorialidade: o portão de entrada da fazenda, feito com duas toras grossas de mogno dispostas em formato de um $\mathrm{T}$ com o nome da fazenda grafado na tora de cima, havia sido interditado, estando o portão batido à prego e acorrentado. Faixas e bandeiras alusivas ao MST indicavam agora a existência de uma outra territorialidade no local, confirmada com o nome recém grafado no portal: Dalcídio Jurandir e, ao lado, o nome antigo, Fazenda Maria Bonita, ganhava um adendo - Ex.

$\mathrm{Na}$ guarita havia dois vigias muito jovens. A regra era clara: qualquer pessoa que quisesse entrar ou sair teria que se identificar, mesmo sendo os próprios acampados. O Liu, coordenador da juventude do acampamento, me advertiu muito sobre este procedimento e recomendou que eu falasse em seu nome quando chegasse. O rapaz que desceu da van junto comigo estava chegando para se cadastrar. Tinha uma tia no acampamento e estava indo ocupar uma das vagas abertas por ocasião das desistências e expulsões do acampamento. A outra pessoa que também chegou na van, foi o pai da Marleide e do Neneco. Havia entrevistado esses dois irmãos no Assentamento 17 de Abril. Eles estavam no acampamento, e mais tarde pude encontrá-los na barraca, bem insatisfeitos por estarem ali, aguardando o pai que havia saído para receber o pagamento em Eldorado.

Um dos vigias era o Quarenta, que me levou até a praça. Já era quase meio-dia, horário do revezamento dos turnos dos grupos de segurança. Na subida até a praça fomos passando por entre os barracos de palha e cruzando com as pessoas que a essa hora se abrigavam do sol quente para fazer a sesta. Parávamos para falar com um e outro, e toda a conversa entabulada pelo Quarenta era sobre comida e almoço. Percebi que isso se tratava de mais uma das tarefas coletivas diárias que aconteciam ali: onde e o que comer? Eu, como não havia almoçado, tratei de arrumar um prato de comida para mim: um pouco de arroz de uma barraca, feijão de outra, uma misturinha em outra, e assim consegui o almoço. A peregrinação foi finalizada na barraca do pai do Neneco, onde me sentei para comer. Quando finalmente cheguei ao local do encontro,

\footnotetext{
1 Graduação em Geografia pela Pontifícia Universidade Católica do Rio de Janeiro (1992), mestrado em Desenvolvimento Sustentável do Trópico Úmido pela Universidade Federal do Pará (2003) e doutorado em Geografia pela Universidade Federal Fluminense, na área de concentração Ordenamento Territorial e Ambiental (2011). Tem experiência na área de ensino da Geografia e em metodologia de pesquisa em Ciências Sociais, atuando principalmente nos seguintes temas: território-territorialidade, campesinato, movimentos sociais e juventude. E-mail: beatrizmfribeiro11@gmail.com.
} 
no barracão da saúde, era meio-dia, sol a pino. O vento quente soprava forte e levantava a poeira que cobria tudo, deixando coisas e pessoas todas num mesmo tom marrom-amarelado. Havia muitos jovens e crianças, e o som ligado estava muito alto. Dois rapazes dançavam muito bem o break, fazendo uma demonstração de suas habilidades, como num desafio. Estavam ensaiando para a "noite cultural" do encontro da juventude.

Por algum tempo não percebi a presença de adultos, homens e mulheres, pelo acampamento. Havia uma reunião da coordenação que acontecia desde a manhã e Liu também estava lá. Enquanto via e ouvia coisas sobre aquela realidade, apareceu Marleide e depois Liu, que propôs que déssemos uma volta para conhecer o acampamento. Fomos os três. Primeiro visitamos a horta do Ezequiel, - um dos coordenadores do acampamento -, uma horta bem diversificada com tomate, pimentão, berinjela, abobrinha, alface, couve, cheiro-verde. Antes passamos pela barraca do professor Rui. Ao lado do seu barraco ele fez uma garagem para guardar o carro. Rui e sua esposa, também professora, moravam em Eldorado dos Carajás e fizeram a opção de vir para os sem-terra: - "Aqui podemos ao mesmo tempo trabalhar como professores e lutar para conseguir uma terra", disseram. Levei filmes sobre o Che Guevara atendendo ao pedido feito por telefone antes da minha ida. A sessão aconteceu na praça do acampamento, na televisão comunitária, sob protestos dos demais acampados que queriam ver a novela da Globo.

Mas, foi na última noite que lá passei que me vi, literalmente, num campo de batalha no front. Naquele dia, pela tarde, ensaiamos a mística que seria apresentada logo mais na noite cultural. A minha personagem era a de uma jornalista do Jornal Nacional, que pedia, ao repórter da televisão local, maiores informações sobre o conflito entre fazendeiros e sem-terra ocorrido na região de Eldorado do Carajás. Da mística, constavam ações de sequestro, violência física e psicológica em meio a tiroteios e assassinatos. Mas eis que na boca da noite deste mesmo dia, fui surpreendida com os fogos que avisavam sobre um perigo iminente. Em virtude de uma missão mal sucedida dos acampados, o chão do acampamento levantou poeira, desta vez não com o vento, mas com a correria de todas as pessoas visivelmente aterrorizadas.

$\mathrm{Na}$ tensão do momento todos já sabiam quais eram os seus papéis, ou seja, onde estar, se posicionar, quem procurar ou o que fazer. Eu, sem entender nada, fiquei bastante assustada com a situação, pois na hora do aviso feito com os foguetes me encontrava no banho. O banheiro era um pouco afastado das barracas, com as paredes não muito altas, feitas de palha, o que me permitia ver um pouco do movimento que estava acontecendo. Apressei-me, e quando saí, já não havia mais ninguém nos arredores da casa. Achei estranho, e rapidamente me arrumei e fui à busca das pessoas. Foi quando me encontrei no front, ao ver a encenação do ensaio da mística se tornando realidade diante dos meus olhos. Meu corpo titubeou e eu não sabia muito bem como me posicionar: qual era o meu papel? o que fazer? Tentei me colocar em cena buscando entendimento junto às mulheres que, com as crianças pequenas no colo, formavam uma roda em frente à escola. Elas não falavam sobre o motivo, mas diziam que um grupo de pessoas do acampamento fora surpreendido pelos jagunços da fazenda, e que ainda ouviram tiros, mas que não se sabia se haviam mortos ou baleados. O pânico era geral. As mulheres conversavam entre si tentando descobrir quem eram os homens e os jovens que estavam no grupo. Liu, o coordenador da juventude, veio ao nosso encontro e propôs à esposa do coordenador que me levasse pra barraca, mas não houve reação da parte dela e eu disse então que não se preocupasse e que ali estaria segura. A pastora gritava ao microfone: - "Crianças, não tomem partido, venham para cá", chamando-as para o barracão da igreja, mas eram poucas as que para lá se direcionavam. A maioria das pessoas corria em direção à guarita, justamente de onde vinha o aviso do perigo, e as demais, mulheres e crianças menores, ficavam na praça do acampamento ao lado da escola. Percebi, neste momento, a disposição dos jovens para o enfrentamento, para o combate, para o con-front-o.

Depois da correria em direção à guarita da castanheira, na divisa com o campo da 
fazenda, uma nova informação fez com que o fluxo se invertesse. Diziam que a polícia estava chegando ao acampamento, e então todos correram em direção à guarita da entrada, na pista da BR-155. Todo este alerta e preparação para o confronto teve a duração de quase 1 hora, até que chegasse a nós a informação de que o grupo dos sem-terra que fora realizar a missão, estaria a salvo. Lá mesmo na guarita da entrada foi realizada uma assembleia dos acampados na qual foi discutida a possibilidade da existência de um informante do fazendeiro dentro do acampamento. Este estaria com os dias contados e nova providência seria tomada com relação aos celulares. Medidas de segurança. Território como controle.

Depois de passado o susto, voltamos à barraca do coordenador. Naquela noite teríamos a festa e a realização da mística preparada durante a tarde. Presumi que depois de toda aquela tensão a mística estaria cancelada. Mas logo percebi que essa suposição correspondia ao lugar social que eu ocupava, o qual me levava a pensar que a realização da mística seria desaconselhável depois do conflito, como se a representação desta realidade, depois de senti-la na pele, fosse desnecessária; ou como se a mística sobre o conflito fosse uma brincadeira e que, no momento em que o acontecimento real desfez o seu caráter lúdico, não haveria mais nenhum sentido realizá-la. Certa, e dentro destes pensamentos, me pus calmamente a jantar na casa vazia do coordenador do acampamento. Todos estavam na praça. Foi quando irrompeu pela barraca adentro o Quarenta: - "E aí Bia, só tá faltando tu pra começar a mística". Eu imediatamente respondi: - "Cês são malucos". Larguei o prato de comida e fomos. Foi a primeira vez que vi a celebração de uma mística onde a fronteira entre o real e o imaginário se desfez. As meninas e os meninos rolavam pelo chão de poeira do acampamento simulando a guerra, tendo como plateia todos os acampados, que em uníssono vibravam. E até a minha encenação no papel da jornalista foi parabenizado por eles. Ao final da minha estadia, em reunião com a juventude, durante a nossa solene despedida, fui convidada por eles para me acampar!

Data de submissão: 27.05 .2021

Data de aprovação: 12.12 .2021 